筋カトレーニングを主とした運動負荷と食事制限の

体構成および血液性状に及ぼす影響

\author{
金子 佳代子*, 矢 吹 恵 子**, 小 池 五 郎** \\ * 横浜国立大学教育学部 \\ ** 女子栄蕌大学
}

\author{
Effects of Strength Training Combined with Energy Restriction on \\ Body Composition and Blood Constituents in Young Women \\ Kayoko KANEKO,* Keiko YABUKI** and Goro KOIKE** \\ * Faculty of Education, Yokohama National University, \\ Yokohama 240 \\ ** Kagawa Nutrition College, Sakado 350-02
}

\begin{abstract}
Nippon Eiyõ Shokuryö Gakkaishi (J. Jpn. Soc. Nutr. Food Sci.) 45, 95 99 (1992)
To assess the effects of strength training and body weight loss on body composition, energy expenditure and blood constituents, nine female students were assigned a supervised program of exercise combined with energy restriction for 12 weeks and compared with four other subjects who remained sedentary. The average energy intake of the subjects was $1,650 \mathrm{kcal} /$ day in the exercise group and 1,870 kcal/day in the sedentary group. Decreases in body weight and body fat content were observed in both groups. In the exercise group, lean body mass increased, and decreases in body weight, body fat content and body size were larger than in the sedentary group. The resting metabolic rate declined to a similar extent in both groups towards the summer. The level of plasma HDL-cholesterol was increased significantly in the exercise group.
\end{abstract}

Key Words exercise, energy restriction, body composition, weight loss, cholesterol.

(Received July 25, 1991)

近年, 肥满の治㞠に食物摂取制限と運動を組み合わせ ることの有效性が認識されている。すなわち，運動が んにェネルギー消费を高めるばかりでなく，詝葴脂肪の 消費増加，体タンパク質の保留，体力の向上などの栍極 的な効果をむつことが明らかにされかー゙; 肥満の治療に 持久的な運動を規則的に行わせることの意味が評価され

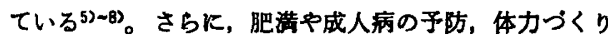
としての運動の効用に咸する研究もさかんになり910), 日本人の栄養所要量11には具体的な運動道量が示される ようになった。

食事・運動の管理は，日常生活の中で継続的に行らこ とができ，習慣化できるるのでなければその効果を維持

* †240 横浜市保土ケ谷区常盤台 156

** 三350-02 坂戸市千代田 3-9-21
することはできない。その具体的な方法について検討 し，基礎的データを得ることを目的として本研究を実施 した。前報122では，香川式 4 群点数法による食事管理と 持久的な逥動を組み合わせることによる体粠成等に及ぼ す影艪について報告した。これに続いて本研究では，筋 カトレーニングを主とした運動を実施することによる体 構成等への影繁について観察した。

\section{研究方 法}

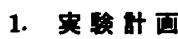

運動部に属さない健康な女子学生 9 名に筋力トレー゙ = ングを 12 週間実施させ,トレーニング開始時 (4月). とトレーニング終了時（6月）、体棈成，周径，皮下脂 肪厚（皮厚)，基礎代既および活動代揤量を測定したの゙。 
血液性状については前記 2 回のはかにトレーニンク開始 後 1 カ月め (5月) にも測定して貣血等の異常の有無を 確かめた。対照群として、トレーニングを実施しない女 子大学生 4 名についても同し時期に, 前記諸項目の湘定 を行った。期間中はトレーニンク群，対照群ともに早朝 空腹時の体重を每日训定し, 食物捸取量, 運動量を各自 記録させた。表 1 に被検者の身体特性を示す。

2. 全

食事は香川式 4 群点数法 ${ }^{13}$ にもとづき，1 群 3 点，2 群 3 点, 3 群 3 点を摄取することとし，4群の摄取点数 を加減して各自エネルギー摂取量を調節した。体重を娍 したい者は 4 群の食品の撕取量を隇らして調節してよい こととし，また分離大豆タンハクク貿 (SPI)の粉末を撕取 してタンパク質撕取量を増加してもよいこととした。そ の他の食品配合等は自由としたが，被釦者は食物の選択

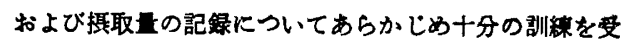
けており，記録は正確を期した。

\section{3. 证功}

運動は，㳙肉に等尺性収䅶を荷することを目的に，筋 カトレーニングを主とし，有酸素運動（エアロビックダ ンス, ショギング, 自転車エルゴメータ等) を組み合わ せて行った。筋カトレーニングは以下の 10 種目につい て実施した。あらかじめ各種目ことに測定した各個人の 最大実施可能回数の $60 \%$ に相当する回数を実施するこ ととし, 10 種目で1コース, 週に3コース実施するこ とをめやすとした。各種目ごとに，実施するめやすとし た回数を（）内に示した。

(1)シットフッフォ (5 32 回), (2)ハッッリフト (12 31 回), (3)ショルダーレイズ (8〜22 回), (4)ダンペルレ イス (6 19 回), (5)フームカール (10 45 回), (6)リス トカール (18 58 回), (7)㷛垂 (1 24 回), (8)ブッシュ アップ(4 18 回), (9) ダンベルフライ (9 22 回), (10)スク ワット(22 132 回), なお, (4)(9)については $2 \mathrm{~kg}$ の鉄 フレイを用いた。

また有酸素運助については前報12) と同様に, Cooper の点数法16に準じて㯰動量を点数化し，過に 18 点を目 票として実施させた。

\section{4. 珝定方法}

1）体重 期間中毎朝起床後に排尿，排便をすませ, ヘルスメータを用いて体重を測定させ，その増減につい ては各自に管理させた。2 回の測定期間中は大学内のメ タボリックニニットに宿泊させ, 精度 $0.01 \mathrm{~kg}$ の台科に て測定した。

2）栄養索摄取量 各自の食事記録をるとに，四訂日 本梅準食品成分表，無機䆩・脂肪酸含是表(5)より，エネ

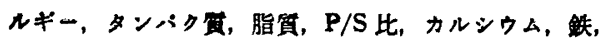
ビタミン（以下, V と略す) $A, V_{1}, V_{B_{2}}$,ナイフシ
表 1. 被䀵者の身体特性

\begin{tabular}{|c|c|c|}
\hline & 筋カトレーニンク群 & 対照群 \\
\hline 例 数 & 9 & 4 \\
\hline 年临命（戧） & $21 \pm 1$ & $20 \pm 1$ \\
\hline 身長（cm） & $157.2 \pm 6.0$ & $157.0 \pm 4.9$ \\
\hline 初体重（kg） & $56.5 \pm 6.7$ & $54.2 \pm 6.3$ \\
\hline
\end{tabular}

ン, VC の摃取且を算出した。

3）体楼成 体脂肪量, Lean Body Mass (LBM), 体水分量を測定した。体脂肪量は，水中体重秤量法によ り体比重を求め，Brozek の式により算出した。体重と 体脂肪の差を LBM とした。体水分量は重水 $10 \mathrm{ml}$ を 経口投与し，尿中重水䈨度をガスクロマトクラフィーK て分析して求めた。剆定方法はいすれれる前報12)と同しで ある。

4) 身体計測身体各部の周径, 皮下脂肪厚（皮原） を測定した。測定箅所, 湘定方法は前報12) と同しであ る。

5）血液検査 早朝空腹時に $10 \mathrm{ml}$ 採血し、ヘマトク リット值 $(\mathrm{Ht})$ ， ヘモグロビン (Hb) 湴度を測定後, 血 洯を分崔し，粉コレステロール(TC)，HDL-コレステ ロール (HDL-C), 中性脂肪 (TG), 血墏タンバク質 (SP) について分析した。测定方法は前報12)と同じであ 万。

6）基礎代䜊および活動代謝量 測定期間中の 3 日間

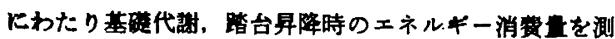
定した。踏台界降時のエネルギ一消費量测定方法は前 報12) と同粎である。

\section{5. 梌定方法}

実䀫結果は平均值士SD で表し，有意差の倹定につい ては実験前・中・後の比較には対応のある差の検定，ま たトレーニンク群と対照群の比較には Student の $t$-検 定を用いた。

なお，本研究はヘルシンキ宜言に則り施行したすので ある。

\section{研究結果および考察}

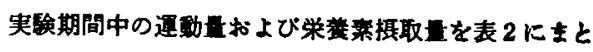
めた。筋カトレーニング平均して遇に2.2 回実施して おり，有酸素運動は 11.8 点/週であり，いデれる目電と

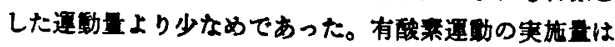
前報 ${ }^{22)}$ 運動負荷クルーブに比べて低值であった。

平均摄取エネルギーはトレーニング群 $1,650 \mathrm{kcal} /$ 日 (30 kcal/kg/日)，対照群 $1,870 \mathrm{kcal} /$ 日 (35 kcal/ kg/ 日）であり，いずれす 20 领代女子の生活活的強度 1 に おけるェネルギー所要田はより低值であった。これは被 


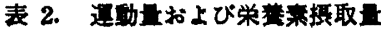

\begin{tabular}{|c|c|c|}
\hline & $\begin{array}{l}\text { 筀力トレー } \\
\text { =ング群 }\end{array}$ & 対照群 \\
\hline \multicolumn{3}{|l|}{ 運野量 } \\
\hline 第カトレーニング & $2.2 \pm 0.4$ & $0.8 \pm 0.2$ \\
\hline 有酸素運動（点/週） & $11.8 \pm 6.7^{*}$ & $5.1 \pm 0.4^{*}$ \\
\hline \multicolumn{3}{|l|}{ 栄篗素摂取量 } \\
\hline エネルギー（kcal/日） & $1654 \pm 222$ & $1873 \pm 114$ \\
\hline 摂取エネルギー/ & $1.5 \pm 0.1^{*}$ & $1.8 \pm 0.1^{*}$ \\
\hline タンパク質 （g/日） & $77.5 \pm 22.3$ & $84.4 \pm 15.1$ \\
\hline 脂質エネルギー比 (\%) & $29.4 \pm 2.0^{*}$ & $32.7 \pm 1.2^{*}$ \\
\hline $\mathrm{P} / \mathrm{S}$ 比 & $0.84 \pm 0.25$ & $0.90 \pm 0.26$ \\
\hline カルシウム & $660 \pm 60^{*}$ & $548 \pm 23^{*}$ \\
\hline (mg/日) & $9.6 \pm 1.7$ & $8.1 \pm 0.4$ \\
\hline ビタミンA (IU/日) & $3175 \pm 670$ & $2780 \pm 376$ \\
\hline ビタミン $\mathrm{B}_{1}$ (mg/日) & $1.0 \pm 0.1$ & $0.9 \pm 0.1$ \\
\hline ビタミン $\mathrm{B}_{2}$ (mg/日) & $1.3 \pm 0.1$ & $1.3 \pm 0.1$ \\
\hline ナイフシン （mg/日） & $12.4 \pm 1.4$ & $11.7 \pm 0.8$ \\
\hline ビタミンC (mg/日) & $135 \pm 20^{*}$ & $94 \pm 18^{*}$ \\
\hline
\end{tabular}

*両群間に有意差あり（ $p<0.05 ） 。$

険者に減盢しよらといら意識があり，とくにトレーニン ク群では運動を実施すると同時にエネルギー撕取量を控 えた結果と考えられる。筋力トレーニング群の平均エネ ルギー搷取量は前報12の運動負荷群とほぼ同じ程度で あった。タンパク質摄取量はSPIを摂取したため,成人女 子の所要量より大となった。脂質エネルギー比は両群と も30\% 前後であり，また鉄については両群とすに，カ ルシウムについては対照群において所要量を下回る乑取 是であった。

実耠期間中の体重変動は各被険者によって多少の䢖い はあったものの, おおむね 12 週間にわたって徐々に減 少する頋向がみられた。体重, 体榙成, 周径および皮厚 の変化を表 3 にまとめた。体重および体脂肪量の滅少は 対照群に比べ筋力トレーニンク群で大であった。LBM はトレーニンク群では有意に增加し, 平均增加量は 1.5

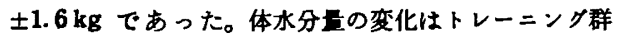
$-1.4 \pm 3.2 \mathrm{~kg}$, 対照群 $-1.7 \pm 2.2 \mathrm{~kg}$ であり，いずれ の群においても有意な変化ではなかった。

近年, 肥满者の減量において, 摂取ェネルギー制限と 運動を組み合わせることにより，LBM を減少させずに 体脂肪を減少させたことが報告されている22 (6)16) -193。 これらの研究では, 歩行, ショギンク,自転車エルコメー タ等の有酸素運動を負荷しており,この上らな運動負 荷によって，食事制限だけでは失敗した人の減量に成功
表 3. 体重, 体脂肪, LBM，体水分，周径および 皮厚の変化

\begin{tabular}{|c|c|c|}
\hline & 筋カトレーニング群 & 対照群 \\
\hline 体 重（kg） & $-1.7 \pm 1.7^{8}$ & $-0.9 \pm 0.8$ \\
\hline 体脂助（kg） & $-3.4 \pm 1.6^{\mathrm{a}, *}$ & $-1.2 \pm 0.7^{2}, *$ \\
\hline LBM（kg） & $+1.5 \pm 1.6^{a}$ & $+0.4 \pm 0.4$ \\
\hline 体水分（kg） & $-1.4 \pm 3.2$ & $-1.7 \pm 2.2$ \\
\hline \multicolumn{3}{|l|}{ 周 径 (cm) } \\
\hline 胸 囲 & $-2.0 \pm 2.6^{a, *}$ & $+1.4 \pm 2.3^{*}$ \\
\hline 腹 囲 & $-2.2 \pm 1.8^{a}$ & $-0.9 \pm 1.8$ \\
\hline 紫 囲 & $-1.8 \pm 2.1^{2}$ & $-0.9 \pm 0.4^{2}$ \\
\hline 大继囲 & $-1.8 \pm 2.7$ & $-1.5 \pm 1.2$ \\
\hline 下腿囲 & $0 \pm 0.9$ & $-0.3 \pm 0.2$ \\
\hline 上胮囲（伸展） & $-0.04 \pm 0.6$ & $+0.7 \pm 0.8$ \\
\hline \multicolumn{3}{|l|}{ 皮原 $(\mathrm{mm})$} \\
\hline 上腕韭部 & $-0.2 \pm 3.3$ & $-2.8 \pm 5.1$ \\
\hline 周甲骨下部 & $-3.3 \pm 5.3$ & $-3.5 \pm 4.1$ \\
\hline 側腹部 & $-1.6 \pm 5.7$ & $+2.3 \pm 5.2$ \\
\hline 腹 部 & $+1.3 \pm 4.0$ & $-1.5 \pm 2.9$ \\
\hline
\end{tabular}

実跧開始時と終了時との間に有意差あり（ $p<$ $0.05) 。 *$ 両群間に有意差あり $(p<0.05)$ 。

したという報告もみられる20)。有酸素運動は貯蔵脂肪か らの脂肪酸の放出を增大することが知られているが21， 食物摄取制限時に有酸素運動を負荷した前報12)では体脂 肪の減少に個人差がみられた。本研究では有酸亲遇動に 筋力トレーニングを組み合わせて実施し体脂肪の減少を みたが、このよらな運動負荷の効果については運動量等 を含めて今後さらに検討を要すると思われる。

最近, Ballor ら ${ }^{223}$ は食事制限と筋カトレーニングを組 み合わせることにより，LBM を增大させながら体重を 減少させらること、エネルギー摂取制限時においても筋 肉の肥大が起こっていることを明らかにしている。前 報122の有酸素運動負荷に怙いて必ずしも LBM の增大 はみられなかったが，本研究で得られた結果をこれと比 較して考察すれば，筋力トレーニングを行らことにより エネルギー摃取制限時において LBM を增加させらる ことが確虫できたといえよう。

周径, 皮厚の变化をみると、䬢カトレーニング群では 胸囲、腹囲、略囲の体幹部の周径が有意に減少してい た。周径の減少 (1前報 ${ }^{12)}$ 運動負荷群と比較して大で あった。筋カトレーニンク群では肩甲骨下部および側腹 部の皮㢖が減少したが，腹部は增加しており，また対照 群と比較して必ずしも皮厚の減少は大きくなかった。さ らに，前報の運動負荷群と比較しても肩甲骨下部および 側腹部での減少は同じ程度であったが,上腕背部,腹部の 増減のようすは異なっていた。また体脂肪の減少量と皮 
厚の変化の間には相烕が認められなかった。最近, James と Susan 28) はエネルギー制限に能カトレーニングを組 み合わせた場合 muscle area が增大, fat area が減少 て，両者を合わせた arm area は增加していたことを上 腕のX線撮影により明らかにしている。ぬた，Johnston ら20は肥満者の減量前後の体脂肪と周径, 肥厚の変化を 調へ，体脂肪の減少は肥厚より周径の変化とよく相関し たことを報告している。本研究においても同様の結果で あり, 皮手の变化についてはその測定方法手含めて今後 検討する必要があると思われた。

表 4 に基礎代謝，活動代謝量の結果を示した。基礎代 謝はトレーニンク群, 対照群ともに, 夏期に向かって低 下寸る傾向が認められた。トレーニング群ではLBM の 增加が認められたにもかかわらず基礎代謝は対照群と同 じように低下していたことから，LBM の多少の増減や この程度の運動負荷が基礎代謝に大きく影暂するすので はないと思われる。踏台昇降時の消费エネルギーは，ト レーニング群，対照群ともに低下したか，これは基礎代 謝低下の影遙とも考えられる、最近，ある程度以上の強 い運動を行らことにより，その後長時間にわたり安静時 のエネルギー消蒷量を間接的に高めること，あるいはそ の後の食事による SDA を高める作用のあることが報告 されている25)26)。しかし，このような効果には運動の強 度，継続時間，頻度等が関連することも指摘されてい ろ2728)。今後このようなエネルギー代謝に及ぼす食事制 限や運動の影辢について詳しく検討する必要があろ5。

表 5 に血液検查の結果をまとめた。HDLーコレステ ロールは筋カトレーニング群で上昇し,TG,TCについて は両群とも変化はみられなかった。前報12)においてす食 事制限群および運動負荷併用群で HDL-コレステロール の上早が双られている。TG，TCは食事や体重の変化に

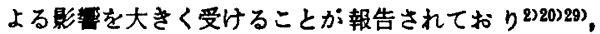
HDL-コレステロールは運動により增加するとの報告す みられる6)299。食事管理に運動を組み合わせることによ り脂質代謝をさらに改善し，心疾患の予防に有効である かどらかについては今後さらに検討か必要であろう。

$\mathrm{Ht}, \mathrm{Hb}$ ，TP はいずれのグルーブむ正常範囲内の数值 であった。太田らりは，中年肥満者にェネルギー制限と 運動負荷を組み合わせて減量を実施したところ，窒素出 納が負を示し，貧血傾向がみられたことを報告してい る。本研究では筋カトレーニンクを負荷することを考虑 してタンパク質摂取貫をやや增大させ，鉄摂取量につい ても注意を促したところ，Hb，TP の低下など分血と判 定される者は認められなかった。本研究における鉄摂取 旺の平均は $9 \mathrm{mg} /$ 日であったが，運動時における分血予 防をる含め，鉄の必要量についてはさらに検討を要する であろう。
表 4. 基礶代謝および踏台㫒降時の消费エネルギー

\begin{tabular}{|c|c|c|}
\hline & $\begin{array}{l}\text { 筋力トレー } \\
=\text { ンク群 }\end{array}$ & 対照群 \\
\hline \multicolumn{3}{|c|}{ 基礎代謝（kcal/kg/日） } \\
\hline 実験開始時 (4 月) & $20.12 \pm 1.83^{\mathrm{a}}$ & $20.31 \pm 1.94$ \\
\hline 実験終了時 ( 6 月) & $18.58 \pm 1.47^{\mathrm{a}}$ & $18.78 \pm 2.00$ \\
\hline \multicolumn{3}{|c|}{ 踏台昇降時の消费エネルギー (kcal/kg/分) } \\
\hline 実験開始時 (4 月) & $0.108 \pm 0.010^{\mathrm{a}}$ & $0.107 \pm 0.014$ \\
\hline 実験終了時 ( 6 月) & $0.101 \pm 0.008^{2}$ & $0.100 \pm 0.009$ \\
\hline
\end{tabular}

a 実豎開始時と終了時との間に有意差あり（ $p<$ 0. 05)。

表 5. 血液性状の変化

\begin{tabular}{|c|c|c|}
\hline & $\begin{array}{l}\text { 筇カトレー } \\
=\text { ンク群 }\end{array}$ & 対照群 \\
\hline \multicolumn{3}{|c|}{$\mathrm{Hb}(\mathrm{g} / \mathrm{dl})$} \\
\hline 4 月 & $13.4 \pm 1.0^{\mathrm{a}}$ & $13.0 \pm 0.4$ \\
\hline 5 月 & $13.9 \pm 0.9^{a}$ & $13.7 \pm 0.8$ \\
\hline 6 月 & $13.8 \pm 1.1$ & $13.5 \pm 0.8$ \\
\hline \multicolumn{3}{|l|}{$\mathrm{Ht} \cdot(\%)$} \\
\hline 4 月 & $42.0 \pm 2.8$ & $39.5 \pm 1.2$ \\
\hline 5 月 & $41.4 \pm 2.8$ & $39.7 \pm 1.2$ \\
\hline 6 月 & $40.6 \pm 2.8$ & $39.2 \pm 1.7$ \\
\hline \multicolumn{3}{|c|}{ 総タンバク質（g/dl plasma） } \\
\hline 4. 月 & $8.8 \pm 0.5$ & $8.5 \pm 0.5$ \\
\hline 5 月 & $8.8 \pm 0.4$ & $8.6 \pm 0.3$ \\
\hline 6 月 & $8.9 \pm 0.5$ & $8.4 \pm 0.5$ \\
\hline
\end{tabular}

中性脂肪 ( $\mu \mathrm{g} / \mathrm{dl}$ plasma)

$\begin{array}{rrrrrr}4 & \text { 月 } & 82 & \pm 37 & 62 & \pm 6 \\ 5 & \text { 月 } & 70 & \pm 18 & 83 & \pm 21 \\ 6 & \text { 月 } & 64 & \pm 12 & 70 & \pm 15 \\ \text { 䋟 } & \text { レステロール } & (\mu \mathrm{g} / \mathrm{dl} \text { plasma }) \\ 4 & \text { 月 } & 175 & \pm 28 & 178 & \pm 13 \\ 5 & \text { 月 } & 175 & \pm 34 & 171 & \pm 27 \\ 6 & \text { 月 } & 187 & \pm 27 & 175 & \pm 18\end{array}$

HDL-コレステロール ( $\mu \mathrm{g} / \mathrm{dl}$ plasma)

$\begin{array}{llllll}4 & \text { 月 } & 56 & \pm 11^{\mathrm{a}, \mathrm{b}} & 59 & \pm 2 \\ 5 & \text { 月 } & 67 & \pm 9^{\mathrm{a}} & 64 & \pm 14 \\ 6 & \text { 月 } & 69 \pm 11^{\mathrm{b}} & 72 & \pm 13\end{array}$

a 4 月と 5 月の間に有意差あり $(p<0.05) 。$ 月 と 6 月の間に有意差あり $(p<0.05)$ 。

以上の結果から，本研究で実施した程度の筋力トレー ニンクを含む運動およびェネルギー制限によって体脂肪 目の減少, LBM の増加, HDL-ュレステロールの上昇 など, 肥满, 成人病の予防や健康增進に好ましい効果の 
得られることが明らかになった。また，掍取エネルギー を制限してるバランスのとれた食事内容であれば顀血な どの異常を起こすこともなく, 健康的に減量できること が明らかになった。Gorsky ら ${ }^{30}$ ( 健康な青年に食事制 限をしたところ日常生活活動における立位, 歩行時間が 減少し，座位の時間が增大したことを報告している。ま た, Pacy ら が脂質代謝等にみられるが，これは罣動そのるのの影響 のほかに，生活に㯰動を取り入れることによって生活ス タイルが変化したために起こる影響を見逃せないとのべ ている。今後, このよらな観点からの研究す必要と思わ れる。

\section{要約}

女子大学生 9 名に筋力トレーニングを主とした運動を 負荷し，その効果について㭘討した。

1）筋力トレーニンクと食事制限により，体重が減少 し，体脂肪量が減少，LBM は增加した。またこれに伴 い体幹部の周径に娍少がみられた。

2）基砝代辄，踏台昇降時の消貲エネルギーには筋力 トレーニンク群と対照群との間に差がみられなかった。

3）血漿中の HDL-コレステロールは筋カトレーニン グ群で上昇したが，中性脂肪, 粉コレステロールには変 化がられなかった。

4）䓢 2 3 回の筋力トレーニングを含む運動と軽い エネルギー制限を組み合わせることにより，LBM の减 少，公血などを防ぎがら，効果的に減量し，かつ健康 を増進させることができると考えられる。

\section{文嘀}

1）太田冨贵雄，大岛寿美子，平山昌子，鈴木傎次郎： 栄落誌，31，230 (1973)

2）鈴木慎次郎, 太田富贵雄, 大島寿美子 : 体育科学, 4, 31 (1976)

3) Zuti, W.B. and Golding, L.A. : Physician Sportsmed., 4, 49 (1976)

4) Buskirk, E.R., Thompson, R.H., Lutwak, L. and Whedon, G.D.: Ann. N.Y. Acad. Sci., 110, 918 (1963)

5) Xavier, F., Pi-Sunyer and Woo, R.: Am. J. Clin. Nutr., 42, 983 (1985)

6) Ravussin, E., Burnand, B., Schutz, Y. and Jequir, E.: Am. J. Clin. Nutr., 41, 753 (1985) 7) Hagan, R.D.: Sports Med., 5, 144 (1988)
8) Hammer, R.L., Barrier, C.A., Roundy, E.S., Bradford, J.M. and Fisher, A.G.: Am. J. Clin. Nutr., 49, 77 (1989)

9）池上晴夫, 佐竹昌之, 黒川隆志, 丹信介, 杉浦 崇夫, 山歌由久：体力科学, 32, 302 (1983)

10) Nishimuta, M., Tsuji, E., Higuchi, M., Hashimoto, I., Yamakawa, K. and Suzuki, S.: 体力 科学, 30, 127 (1981)

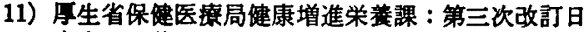
本人の栄菱所要量, (1984), 第一出版 (東京)

12）石川和子，鉿木則子，小林桂子，鬼 和美，神尾 典子，大内雅恵，金子佳代子，小池五郎：女子栄 盖大学紀要, 21, 71 (1990)

13）香川考子：なにをどれだけ食べたらよいか,(1983) 女子栄美大学出版部 (東京)

14) Cooper, K.H.: The New Aerobics, (1970) ; (加

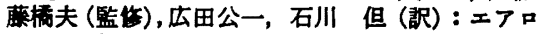
ビクス,(1982)，ベースボールマガジン社(東京))

15）食品成分研究会（編）：食品の食物誠維・無機質. コレステロール・脂肪酸含量表，（1986），医歯薬 出版 (東京)

16) Weltman, A., Matter, S. and Stanford, B.A.: Am. J. Clin. Nutr., 33, 1002 (1980)

17) Hill, J.O., Sparling, P.B., Shields, T.W. and Heller, P.A. : Am. J. Clin. Nutr., 46, 622 (1987)

18) Hill, J.O., Schlundt, D.G., Sbrocco, T., Sharp, T., Pope-Cordle, J., Stetson, B., Kaler, M. and Heim, C. : Am. J. Clin. Nutr., 50, 248 (1989)

19) Dale, D. and Saris, W.H.M. : Am. J. Clin. Nutr., 49, 409 (1989)

20) Lewis, S., Haskell, W.L., Wood, P.D., Manoogian, N., Bailey, J.E. and Pereira, M.B.: Am. J. Clin. Nutr., 29, 151 (1976)

21）斉藤 茂, 池田義雄 : 保健の科学, 23，33 (1981)

22) Ballor, D.L., Katch, V.L., Becque, M.D. and Marks, C.R. : Am. J. Clin. Nutr., 47, 19 (1988)

23) James, W.A. and Susan, R.B.: Am. J. Clin. Nutr., 47, 440 (1988)

24) Johnston, F.E., Wadden, T.A., Stunkard, A.J., Pena, M., Wang, J., Pierson, R.N. and Van Itallie, T.B. : Am. J. Clin. Nutr., 47, 225 (1988)

25) Bahr, R. and Maehlum, S.: Acta Physiol. Scand., 128 (Suppl. 556), 99 (1986)

26) Schutz, Y., Bessard, T. and Jequier, E.: Am. J. Clin. Nutr., 45, 1424 (1987)

27) Mole, P.A.: Sports Med., 10, 72 (1990)

28) Brehm, B.A. : Sports Med., 6, 72 (1988)

29) Goldberg, L. and Elliot, D.L.: Sports Med., 4, 307 (1987)

30) Gorsky, R.D. and Calloway, D.H.: Hum. Biol., 55, 577 (1983)

31) Pacy, P.J., Webster, J. and Garrow, J.S. : Sports Med., 3, 89 (1986)

(1991 年 7 月 25 日受理) 